\title{
Study the Possibility of Manufacturing Therapeutic Ice Cream by Adding Synbiotic and Study its Microbiological and Sensory Characteristics
}

\author{
Sarmad Ghazi Al-Shawi* (iD) and Haider Ibrahim Ali \\ Department of Food Science, Agriculture College, Basrah University, Basra, Iraq.
}

\begin{abstract}
The study was conducted to prepare control, probiotic (Lactobacillus acidophilus), and synbiotic ( $L$. acidophilus and inulin) ice cream, L. acidophilus content, $\mathrm{pH}$, titratable acidity, sensory properties were evaluated during frozen storage periods. L. acidophilus counts were the higher in synbiotic ice cream, adding inulin to probiotic ice cream enhanced significantly $(P<0.05)$ the content of $L$. acidophilus. Freezing process caused a decrease in $L$. acidophilus counts along with storage periods in all the samples of ice cream. Synbiotic ice cream was the lower in $\mathrm{pH}$ values and the higher in TA values compared to the other ice cream samples. Synbiotic ice cream was the better in overall acceptance followed by probiotic and control ice cream, respectively. So, ice cream fortification with $L$. acidophilus probiotic bacteria and prebiotic inulin have a positive influence on all sensory characteristics. Probiotic content of both synbiotic and probiotic ice cream could be considered as functional therapeutic healthy product since it was more than the lowest concentration of probiotic bacteria to provide the beneficial attributes which are $10^{6} \mathrm{cfu} / \mathrm{g}$ at the consumption time of the product.
\end{abstract}

Keywords: L. acidophilus, Inulin, synbiotic ice cream, probiotic ice cream, viable counts

\footnotetext{
*Correspondence: sarmadghazi@yahoo.com

(Received: June 12, 2020; accepted: July 11, 2020)

Citation: Al-Shawi SG, Ali HI. Study the Possibility of Manufacturing Therapeutic Ice Cream by Adding Synbiotic and Study its Microbiological and Sensory Characteristics. J Pure Appl Microbiol. 2020;14(3):2147-2156. doi: 10.22207/JPAM.14.3.55

(C) The Author(s) 2020. Open Access. This article is distributed under the terms of the Creative Commons Attribution 4.0 International License which permits unrestricted use, sharing, distribution, and reproduction in any medium, provided you give appropriate credit to the original author(s) and the source, provide a link to the Creative Commons license, and indicate if changes were made.
} 


\section{INTRODUCTION}

Ice cream is a nutritious frozen milkbased product, eaten widely all over the world for its taste and the nutritional value. The $\mathrm{pH}$ of ice cream is about ${ }^{6-7}$ which regards as a neutral $\mathrm{pH}$, with long storage period. Dairy products represent an ideal source and good media to carry probiotic bacteria into the intestinal tract of human because it provides the required favorable environment which improves probiotic bacteria growth (Salem et al., 2005; Darukaradhya et al., 2006; Homayouni et al., 2008). Probiotics are live microorganisms which when administrated in adequate amount confer healthy effects on the human (Hill et al., 2014). Probiotics enhance the balance of the intestinal microbial content, stimulate the growth of the good bacteria over the intestinal bad bacteria and then improving the host health and lowering the diseases of GIT when an adequate amount is consumed $\left(\geq 10^{6}\right.$ $\mathrm{cfu} / \mathrm{g}$ ) (Bansal et al., 2016; Sangsila et al., 2016). While prebiotics definition is: food ingredients that are indigestible and have a positive effect on the health of the host through stimulating the activity and the growth of the beneficial bacteria of the intestinal tract (Zhang et al., 2018). Many researchers have studied probiotic bacteria survivability in ice cream manufactured in different techniques, such as cultured and nonfermented ice cream mixtures (Akın 2005; Turgut and Cakmakci 2009; Pandiyan et al. 2012). Adding of probiotics and prebiotics to ice cream will add a nutritious value by improving its functional properties (Balthazar et al., 2015; Ozturk et al., 2018). Thus, prebiotics are added to ice cream to boost the growth and the activity of probiotic bacteria in ice cream components. At consumption time, the most important value of dairy products is the viable number of probiotics bacteria which determines the product efficiency (Mortazavian and Sohrabvandi 2006). So, to get the consumers' trust in ice cream and dairy probiotic products, it is very important to keep an acceptable level of bacteria during the production and the shelf life period of the product (Saxelin et al. 1999). The survivability and metabolic activity of probiotic bacteria should be maintained in every step of ice cream manufacturing till the ingestion time by consumers, in addition to keeping their ability to survive in GIT (Sanz, 2007). Many researchers have evaluated probiotic bacteria lowest concentration to provide the positive attributes which is $10^{6}$ $\mathrm{cfu} / \mathrm{g}$ at the consumption time of the product (Kurmann and Rasic 1991; Rybka and Kailasapathy 1995; Blanchette et al. 1996; Gomes and Malcata 1999). Also, the ingestion of $10^{8}-10^{9} \mathrm{cfu}$ per day of probiotic bacteria is required to provide desirable healthy effects to humans (Vinderola et al. 2000; Oliveira et al. 2001). Producing synbiotic or probiotic ice cream with good organoleptic characteristics is not easy and needs a technical knowledge by processors (Aryana \& Summers, 2006; Favaro-Trindade et al., 2006). Nevertheless, probiotic bacteria will not modify the product's sensory characteristics intensely (Champagne et al., 2005). Although, it could be producing a desired quality of probiotic and synbiotic ice cream (Vardar \& Oksuz, 2007).

Study aims to manufacture control, probiotic (L. acidophilus), synbiotic (probiotic Lactobacillus acidophilus and prebiotic inulin) ice cream, and study probiotic bacteria content, $\mathrm{pH}$, titratable acidity and the sensory properties (flavor and taste, body and texture, and color and appearance) over a 28 day of storage period, and subsequently the possibility of manufacturing therapeutic ice cream and extending its shelf life.

\section{MATERIALS AND METHODS \\ Ice cream manufacturing}

Three ice cream samples $(3 \mathrm{~kg}$ for each sample) were manufactured. The mixtures components as shown in Table 1 , were homogenized together according to Arbuckle (1986) with some modification, after that mixtures were heated up to $80^{\circ} \mathrm{C}$ for 30 second, then cooled to $5^{\circ} \mathrm{C}$, left at $5^{\circ} \mathrm{C}$ overnight for aging. Control ice cream prepared without any further addition.

Table 1. Ice cream mixtures components

\begin{tabular}{lccc}
\hline Ingredients & $\begin{array}{c}\text { Control } \\
\text { ice-cream }\end{array}$ & $\begin{array}{c}\text { Probiotic } \\
\text { ice cream }\end{array}$ & $\begin{array}{c}\text { Synbiotic } \\
\text { Ice cream }\end{array}$ \\
\hline Milk fat \% & 8 & 8 & 8 \\
Milk solid non- & 12 & 12 & 12 \\
fat (MSNF) \% & & & \\
Sugar & 16 & 16 & 16 \\
Stabilizer & 0.3 & 0.3 & 0.3 \\
Emulsifier & 0.2 & 0.2 & 0.2 \\
Vanilla flavor \% & 0.3 & 0.3 & 0.3 \\
\hline
\end{tabular}


Probiotic ice cream sample was made by adding (1\% v/v) L. acidophilus log $9 \mathrm{cfu} / \mathrm{ml}$. Synbiotic ice cream sample was made by adding $(1 \% \mathrm{v} / \mathrm{v}) L$. acidophilus log $9 \mathrm{cfu} / \mathrm{ml}$ in addition to $2 \%$ inulin. Each sample then divided into $(100 \mathrm{ml})$ plastic covered cup and kept in freezer at $-18^{\circ} \mathrm{C}$ during the storage periods of 28 days.

\section{Probiotic bacteria enumeration}

Ten grams of ice cream were diluted in $(100 \mathrm{ml})$ sterilized peptone water $(0.1 \%), 1 \mathrm{ml}$ of the diluted ice cream was poured on (MRS) NNLP agar, where NNLP is (nalidixic acid, neomycin sulfate, lithium chloride, and paromomycin sulfate) (Tharmaraj and Shah, 2003). Incubation was conducted under anaerobic conditions at $37^{\circ} \mathrm{C}$ for $72 \mathrm{~h}$. The results of enumeration were calculated as (cfu/g) colony forming units/gram of sample. All samples enumerations were conducted in triplicate.

Titratable acidity and $\mathrm{pH}$ determination

A hundred gram of ice cream from each sample was melted at $5^{\circ} \mathrm{C}$, then acidity was measured by titration the melted ice cream samples against $0.1 \mathrm{~N} \mathrm{NaoH}$ and using phenolphthalein as indicator. The $\mathrm{pH}$ was measured using $\mathrm{pH}$ meter.

\section{Sensory evaluation}

Sensory evaluation was accomplished by 5 specialists and based on the following rating scales: Flavor and taste (1-10), body and texture (15), and color and appearance (1-5) and conducted weekly during the storage periods (Homayouni et al., 2005).

\section{RESULTS AND DISCUSSION}

Table 2 illustrates the changes in Lactobacillus acidophilus counts of probiotic and synbiotic ice cream samples throughout 28 days of storage periods. The viable counts of $L$. acidophilus were 7.95 and $7.98 \mathrm{log} \mathrm{cfu} / \mathrm{g}$ in probiotic and synbiotic ice cream samples, respectively at zero time, and decreased gradually during the storage periods to reach 6.95 and $7.21 \mathrm{log} \mathrm{cfu} / \mathrm{g}$ for probiotic and synbiotic ice cream samples, respectively at storage periods' end. L. acidophilus counts in both probiotic and synbiotic samples were higher than Prashanth et al., (2018) who found that $L$. acidophilus counts ranged between 6.12 and $6.91 \mathrm{log} \mathrm{cfu} / \mathrm{g}$ in ice cream synbiotic sample. The mean of synbiotic L. acidophilus counts sample was higher than the mean of probiotic ice cream sample. Inulin addition to ice

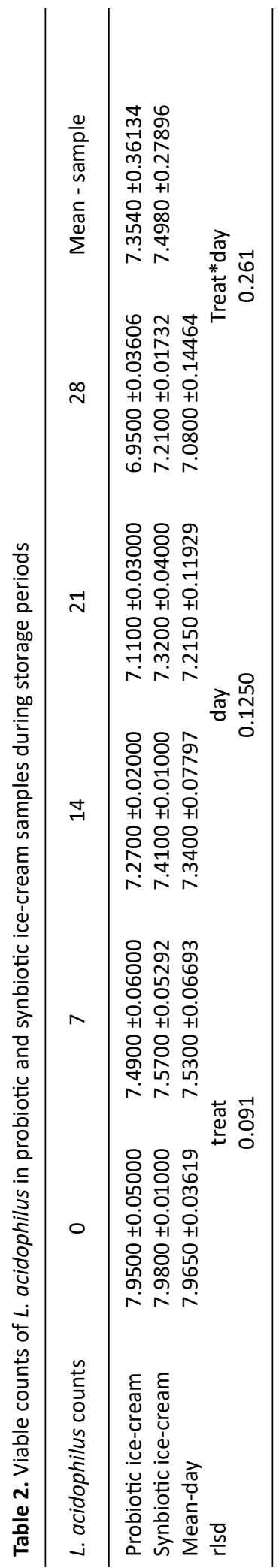

www.microbiologyjournal.org 


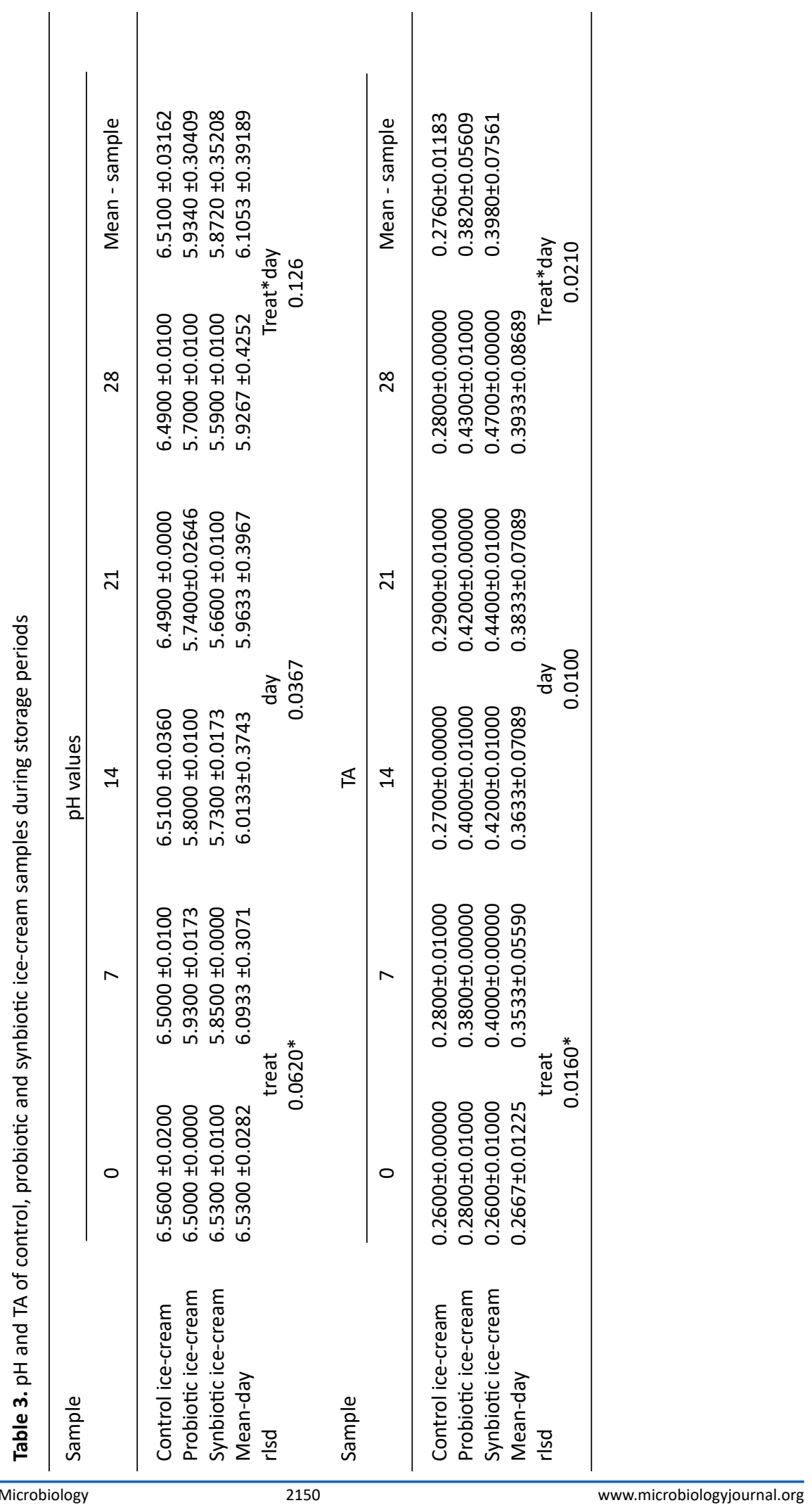


cream (synbiotic) sample significantly $(P<0.05)$ improved probiotic $L$. acidophilus growth, and there were significant $(P<0.05)$ differences in $L$. acidophilus counts between probiotic and synbiotic ice cream samples on day 14 until the end of the storage periods. The increase in $L$. acidophilus counts of synbiotic compared to probiotic samples in this study may be attributed to prebiotic inulin which acts as a protective mechanism during the storage (Prashanth et al., 2018), and this in one line with Pandiyan et al. (2012a) who found that adding FOS to ice cream mixture significantly $(P<0.01)$ enhanced $L$. acidophilus cultures' growth. Furthermore, inulin enrichment to ice cream affected significantly on probiotic bacteria counts (Akin et al., 2007). Furthermore, ice cream enriched with inulin improved significantly $(P<0.01)$ L. acidophilus growth (Pandiyan et al., 2012b). Also, study results agreed with Ayar et al. (2018) who reported that adding inulin and fibers of grain and fruit to ice cream samples affected positively on L. acidophilus counts, inulin ice cream was the higher in $L$. acidophilus counts followed by fibers of grain and fruit ice cream compared to the negative control. Inulin could be used by probiotic bacteria as a source of energy (Rastall, 2010), and this may clarify the reason behind increasing $L$. acidophilus counts in inulin (synbiotic) ice cream sample. On the contrary, there wasn't any effect for inulin on the survivability of $L$. casei 01 of synbiotic ice cream during the passage time via artificial GIT environment (Balthazar et al., 2018). There was a significant decrease in $L$. acidophilus counts in probiotic ice cream sample along with storage periods comparing with a limited significant decrease for $L$. acidophilus counts in synbiotic ice cream sample until the day 14 which was non-significant reduction till the end of storage periods. The reduction in the microorganisms' numbers, resulting from freezing, is probably because of freeze injury which led to cells death. Although the decrease in the counts of probiotic L. acidophilus, the manufactured probiotic and synbiotic ice cream samples might be regarded as a probiotic diet along with the 28 days of the storage period, since $L$. acidophilus counts remained above the minimum limits of $10^{6} \mathrm{cfu} / \mathrm{g}$ at product consumption' time (Vinderola \& Reinheimer, 2000; Argentina, 2013). Likewise, Balthazar et al., (2018) found that all control, probiotic and synbiotic ice cream mixtures improved the growth of $L$. casei 01 and kept its counts higher than the minimum limits $(\log 6 \mathrm{cfu} / \mathrm{ml})$ to be therapeutically during storage. In same line, Akalin and Erisir (2008) reported that many studies have been conducted in different places in the world, results showed that probiotic cultures had the ability to keep their stability in frozen manufactured food, and lost minimum of their viability.

Table 3 shows the $\mathrm{pH}$ and titratable acidity (TA) values of control, probiotic and synbiotic manufactured ice cream during storage periods. At zero time, $\mathrm{pH}$ values were $6.56,6.50$, and 6.53, while TA values were $0.26,0.28$, and 0.26 for control, probiotic and synbiotic ice-cream samples, respectively. $\mathrm{pH}$ values decreased while TA values increased gradually during storage periods to reach $6.49,5.70$, and 5.59 for $\mathrm{pH}$ and $0.28,0.43$, and 0.47 for TA values for control, probiotic and synbiotic ice-cream samples, respectively after 28 days of storage. For $\mathrm{pH}$ values, the lowest $\mathrm{pH}$ value was synbiotic ice cream sample at ending of storage period followed by probiotic and control ice cream samples, respectively. While for TA values, synbiotic ice cream sample also was the highest TA at ending of storage period followed by probiotic and control ice cream samples, respectively.

Ice cream enriched with probiotic bacteria is more acid than the control ice cream, because of lactic acid production via probiotic bacteria (Basyigit et al., 2006). While, addition of inulin to ice cream fortified with probiotic bacteria encouraged the activity of probiotic bacteria and subsequently decreased the $\mathrm{pH}$ and increased the TA. This finding was in agreement with GulerAkin et al. (2016) who reported that there was a reduction in the $\mathrm{pH}$ and an increase in the titratable acidity in carob extract and whey powder enriched-ice cream samples, the metabolic activity of probiotic bacteria was stimulated by adding the extract of carob and the powder of whey. Also, Ayar et al. (2018) attributed the probiotic ice cream protective affects to the fiber addition which led to the relatively low $\mathrm{pH}$. Clear significant differences $(\mathrm{P}<0.05)$ were found among all samples for $\mathrm{pH}$ and TA values, which means that addition of probiotic bacteria and prebiotic affected significantly on ice cream $\mathrm{pH}$ and TA. Control ice cream values ranged 
between 0.26 and 0.28 and these results were close to Barman et al. (2017) who found that the titratable acidity of ice cream samples in Kolkata and its Suburbs ranged from $0.235 \%$ to $0.275 \%$ lactic acid. The relatively low $\mathrm{pH}$ and high TA did not affect somehow on probiotic $L$. acidophilus since the resistance to $\mathrm{pH}$ and acidity is straindependent in probiotic bacteria, and it has been found that $L$. acidophilus has a wide cytoplasmic buffering capacity (3.72-7.74) of $\mathrm{pH}$, which enables it to be stable and resistible to the cytoplasmic $\mathrm{pH}$ changing under the acidic environment (Godward et al. 2000; Tamime et al. 2005). The pH values mean of synbiotic and probiotic ice cream samples ranges from 5.87 to 5.93 during frozen storage and this in one line with Thaochalee et al. (2018) who reported that the mean $\mathrm{pH}$ values of the synbiotic ice creams range from 5.75 to 5.95 during frozen storage, and this is within the optimal growth $\mathrm{pH}$ range for $L$. acidophilus (5.5-6.0) as reported by Mohammadi et al. (2011). Also, the titratable acidity mean increased from 0.2760 in control ice cream to 0.3980 in synbiotic ice cream and this was in line with Prashanth et al. (2018) who reported that elevation of TA means correlated with increasing the levels of prebiotic green banana flour, this elevation may be attributed to the various organic acids compounds in prebiotic banana flour (Prashanth et al., 2018). The final pH of all ice cream samples was within the optimal limited for the product because of the ice cream is not counted as an acidic product, and the low

Table 4. Sensory properties of control, probiotic and synbiotic ice-cream samples during storage periods

\begin{tabular}{|c|c|c|c|c|}
\hline $\begin{array}{l}\text { Flavor and } \\
\text { taste }\end{array}$ & $\begin{array}{l}\text { Control } \\
\text { Ice cream }\end{array}$ & $\begin{array}{l}\text { Probiotic } \\
\text { Ice cream }\end{array}$ & $\begin{array}{l}\text { Synbiotic } \\
\text { Ice cream }\end{array}$ & Mean-day \\
\hline 0 & $9.60 \pm 0.548$ & $9.60 \pm 0.548$ & $9.80 \pm 0.447$ & $9.67 \pm 0.488$ \\
\hline 7 & $9.00 \pm 0.707$ & $9.20 \pm 0.447$ & $9.60 \pm 0.548$ & $9.27 \pm 0.594$ \\
\hline 14 & $8.80 \pm 0.837$ & $9.00 \pm 0.000$ & $9.20 \pm 0.447$ & $9.00 \pm 0.535$ \\
\hline 21 & $8.20 \pm 0.447$ & $8.60 \pm 0.548$ & $9.00 \pm 0.707$ & $8.60 \pm 0.632$ \\
\hline 28 & $7.60 \pm 0.548$ & $8.00 \pm 0.707$ & $8.80 \pm 0.447$ & $8.13 \pm 0.743$ \\
\hline Mean - sample & $8.64 \pm 0.907$ & $8.88 \pm 0.726$ & $9.28 \pm 0.614$ & \\
\hline rlsd & \multicolumn{2}{|c|}{$\begin{array}{l}\text { treat } \\
0.40\end{array}$} & $\begin{array}{l}\text { day } \\
0.47^{*}\end{array}$ & $\begin{array}{c}\text { Treat*day } \\
\text { ns }\end{array}$ \\
\hline $\begin{array}{l}\text { Body and } \\
\text { texture }\end{array}$ & $\begin{array}{l}\text { Control } \\
\text { Ice cream }\end{array}$ & $\begin{array}{l}\text { Probiotic } \\
\text { Ice cream }\end{array}$ & $\begin{array}{l}\text { Synbiotic } \\
\text { Ice cream }\end{array}$ & Mean-day \\
\hline 0 & $4.40 \pm 0.894$ & $4.40 \pm 0.894$ & $4.60 \pm 0.548$ & $4.47 \pm 0.743$ \\
\hline 7 & $4.00 \pm 0.707$ & $4.20 \pm 0.447$ & $4.40 \pm 0.548$ & $4.20 \pm 0.561$ \\
\hline 14 & $3.80 \pm 0.447$ & $4.00 \pm 0.000$ & $4.20 \pm 0.447$ & $4.00 \pm 0.378$ \\
\hline 21 & $3.40 \pm 0.548$ & $3.60 \pm 0.548$ & $4.00 \pm 0.000$ & $3.67 \pm 0.488$ \\
\hline 28 & $3.00 \pm 0.707$ & $3.40 \pm 0.548$ & $3.80 \pm 0.447$ & $3.40 \pm 0.632$ \\
\hline Mean - sample & $3.72 \pm 0.792$ & $3.92 \pm 0.640$ & $4.20 \pm 0.500$ & \\
\hline rlsd & & & & $\begin{array}{c}\text { Treat*day } \\
\text { ns }\end{array}$ \\
\hline $\begin{array}{l}\text { Color and } \\
\text { appearance }\end{array}$ & $\begin{array}{l}\text { Control } \\
\text { Ice cream }\end{array}$ & $\begin{array}{l}\text { Probiotic } \\
\text { Ice cream }\end{array}$ & $\begin{array}{l}\text { Synbiotic } \\
\text { Ice cream }\end{array}$ & Mean-day \\
\hline 0 & $5.00 \pm 0.000$ & $4.60 \pm 0.548$ & $4.80 \pm 0.447$ & $4.80 \pm 0.414$ \\
\hline 7 & $4.40 \pm 0.548$ & $4.40 \pm 0.548$ & $4.60 \pm 0.548$ & $4.47 \pm 0.516$ \\
\hline 14 & $3.80 \pm 0.447$ & $4.00 \pm 0.707$ & $4.40 \pm 0.548$ & $4.07 \pm 0.594$ \\
\hline 21 & $3.40 \pm 0.548$ & $3.80 \pm 0.447$ & $4.20 \pm 0.447$ & $3.80 \pm 0.561$ \\
\hline 28 & $3.40 \pm 0.548$ & $3.60 \pm 0.548$ & $3.80 \pm 0.447$ & $3.60 \pm 0.507$ \\
\hline Mean - sample & $4.00 \pm 0.764$ & $4.08 \pm 0.640$ & $4.36 \pm 0.569$ & \\
\hline rlsd & & & & $\begin{array}{c}\text { Treat*day } \\
\text { ns }\end{array}$ \\
\hline
\end{tabular}


$\mathrm{pH}(4.0-4.5)$ values have undesirable effect on the acceptance characteristics, while study results showed that the final $\mathrm{pH}$ values ranged from 5.59 to 6.49 after 28 days of frozen storage.

Sensory properties evaluation (flavor and taste, body and texture, color and appearance) was conducted to all ice cream samples to determine the acceptance of ice cream samples as illustrated in Table 4. All tested sensory properties were close to each other at zero time for control, probiotic and synbiotic ice cream samples and ranged between 9.60-9.80 for flavor and taste, 4.40- 4.60 for body and texture, and $4.80-5.00$ for color and appearance. Along with increasing the storage periods, the sensory properties decreased slightly, where flavor and taste scored 7.60, 8.00 and 8.80 , body and texture scored $3.00,3.40$ and 3.80 , and color and appearance scored $3.40,3.60$ and 3.80 for control, probiotic and synbiotic ice cream samples, respectively after the frozen storage of 28 days.

The synbiotic ice cream was the higher scores in all sensory properties followed by probiotic and control ice cream samples, respectively, and this finding agreed with Thaochalee et al., (2018) who found that the evaluated sensory characteristics showed a good acceptability for all synbiotic ice cream samples. Adding prebiotic inulin, affected positively on the sensory characteristics of synbiotic ice cream sample for the current study and this result agreed with Vardar and Oksuz (2007) who found that good sensory properties resulted from artisan strawberry ice-cream enriched with $L$. acidophilus. Also, adding unripe banana flour as prebiotic to probiotic ice cream gained the higher overall acceptability scores by the consumers (Prashanth et al., 2018). Furthermore, Cruz et al., (2010) also assured that prebiotic ingredients supplemented to ice cream had a higher influence on texture and flavor. While, Vital et al., (2018) illustrated that there were no significant differences resulted from the addition of the residue of grape juice on sensory properties of ice cream. Addition of L. acidophilus to ice cream affected positively on sensory properties of current study and this result resembles the finding of Vijayageetha et al. (2011) who reported that probiotic L. acidophilus and Bifidobacterium mixture ice cream was noted to has the higher flavor score. On contrary, a low effect on the texture, flavor or the other sensory properties have been found when ice cream fortified with probiotic bacteria (Mohammadi et al., 2011). Also, the sensory properties of ice cream have not affected by adding free and microencapsulated probiotics strains (EL-Sayed et al., 2014).

The mean values of all tested sensory properties were the highest for synbiotic ice cream sample followed by probiotic and control ice cream samples, respectively. No significant differences $(P<0.05)$ were found among most of ice cream samples sensory properties especially during the first two weeks, while clear significant differences $(P<0.05)$ were found between synbiotic ice cream sensory properties and the control ice cream, and slightly between probiotic ice cream and control ice cream, while no significant differences $(P<0.05)$ were found between probiotic and synbiotic ice cream samples. These findings somehow, disagree with Ayar et al. (2018) who found that all sensory properties of ice cream samples were significantly $(P<0.05)$ influenced by adding different fiber material. Also on contrary with Pandiyan, (2014) who found a significant difference $(P<0.05)$ among the treatments in the total sensory scores, while all probiotic and synbiotic ice cream samples recorded lower values in the scores of the total sensory comparing with the control. Furthermore, the sensory properties of probiotic (Bifidobacterium BB-12) ice cream enriched with xylitol, isomalt, maltitol and erythritol were inconsistent and not unanimous (Kalicka et al., 2019). The first indicator regarding food choice is the flavor, followed by the attributes health benefits, if the added supplements provide undesirable flavors to the product, consumers will never consume the therapeutic ice cream although this functional food will improve their health. Probiotic ice cream could provide different flavor properties comparing with the conventional one, while adding of inulin to ice cream will offer some suitable properties and these properties are responsible somehow for the sensory acceptance high score values of synbiotic ice cream.

\section{CONCLUSION}

The population of L. acidophilus in probiotic and synbiotic ice cream was higher than the therapeutic minimum level during the 
manufacturing and storage periods, so it could be count as probiotic food. Also, addition of inulin affected significantly on $L$. acidophilus counts and sensory properties in both probiotic and synbiotic ice cream. It is suggested that ice cream could be effectively used as a carrier to deliver probiotic bacteria in addition to prebiotic supplements such as inulin to improve the gut health of human. The success of therapeutic probiotic and synbiotic dairy products depends on consumer acceptance to such products in addition to its health benefits. So, paying more attention for the sensory properties in addition to the health benefits of these products as therapeutic products and functional food is the key to develop it. Thus, extra studies are required to evaluate the survival and diversity of probiotic bacteria in addition to looking for the best prebiotic to be enriched to gain the required viable number and preferred sensory properties for the product and subsequently for consumers.

\section{ACKNOWLEDGMENTS}

None.

\section{CONFLICT OF INTEREST}

We, the authors declare that there is no conflict of interest.

\section{AUTHORS' CONTRIBUTION}

SGA and HIA Conceived and designed the analysis and collected the data. SGA performed the analysis and wrote the paper. Both the authors approved the manuscript for final publication.

\section{FUNDING}

None.

\section{ETHICS STATEMENT}

This article does not contain any studies with human participants or animals performed by any of the authors.

\section{DATA AVAILABILITY}

All datasets generated or analyzed during this study are included in the manuscript

\section{REFERENCES}

1. Akalin AS, Erisir D. Effects of inulin and oligofructose on the rheological characteristics and probiotic culture survival in low-fat probiotic ice cream. Journal of Food Science. 2008;73(4):M184-M188. doi: 10.1111/j.17503841.2008.00728.x

2. Akin MS. Effects of inulin and different sugar levels on viability of probiotic bacteria and the physical and sensory characteristics of probiotic fermented icecream. Milchwissenschaft. 2005;60(3):297-301.

3. Akin MB, Akin MS, Kirmaci Z. Effects of inulin and sugar levels on the viability of yogurt and probiotic bacteria and the physical and sensory characteristics in probiotic ice-cream. Food Chemistry. 2007;104(1):9399. doi: 10.1016/j.foodchem.2006.11.030

4. Arbuckle WS. Ice Cream. Second Ed., AVI Publishing Company Inc., Westport, Connecticut, USA. 1986:325326.

5. Argentina. Ministerio de Salud de la Nacion. Administracion Nacional de Medicamentos, Alimentos, y Tecnologia Medica - ANMAT. Declarase vigente en todo el territorio de la Republica, con la denominacion de Codigo Alimentario Argentino (Ley 18.284). Boletin Oficial de la Republica Argentina. 2013 . Retrieved from http://www. anmat.gov.ar/alimentos/normativas_ alimentos_caa.asp

6. Aryana KJ, Summers M. Probiotic, fat-free, no sugaradded ice cream. Milchwissenschaft. 2006;61(2):184187.

7. Ayar A, Sicramaz H, Ozturk S, Ozturk Yilmaz S. Probiotic properties of ice creams produced with dietary fibres from by-products of the food industry. International Journal of Dairy Technology. 2018;71(1):174-182. doi: 10.1111/1471-0307.12387

8. Balthazar CF, Silva HLA, Celeguini RMS, et al. Effect of galactooligosaccharide addition on the physical, optical, and sensory acceptance of vanilla ice cream. Journal of Dairy Science. 2015;98(7):42664272. doi: 10.3168/jds.2014-9018

9. Bansal S, Mangal M, Sharma SK, Yadav DN, Gupta RK. Optimization of process conditions for developing yoghurt like probiotic product from peanut. LWT. 2016;73:6-12. doi: 10.1016/j.Iwt.2016.04.059

10. Balthazar CF, Silva HL, et al. Corrigendum to "The addition of inulin and Lactobacillus casei 01 in sheep milk ice cream" [Food Chem. 2018;246:464472]. Food chemistry. 2018;252:397. doi: 10.1016/j. foodchem.2018.01.186

11. Barman AK, Roy PK, Ray S, Kumar R, Rani B, Singh BK. Evaluation of microbiological quality of Ice-cream available in Kolkata and its Suburbs. The Pharma Innovation. 2017;6(8):377-380.

12. Basyigit $G$, Kuleasan $H$, Karahan AG. Viability of human-derived probiotic lactobacilli in ice cream produced with sucrose and aspartame. J Ind Microbiol Biotechnol. 2006;33(9):796-800. doi: 10.1007/s10295006-0128-x

13. Blanchette L, Roy D, Belanger G, Gauthier SF. Production of cottage cheese using dressing fermented by bifidobaceria. Journal of Dairy Science. 1996;79(1):815. doi: 10.3168/jds.S0022-0302(96)76327-0

14. Champagne CP, Gardner NJ, Roy D. Challenges in the addition of probiotic cultures to foods. Crit Rev Food Sci Nutr. 2005;45(1):61-84. doi: $10.1080 / 10408690590900144$ 
15. Cruz AG, Cadena RS, Walter EH, et al. Sensory analysis: relevance for prebiotic, probiotic, and synbiotic product development. Comprehensive Reviews in Food Science and Food Safety. 2010;9(4):358-373. doi: 10.1111/j.1541-4337.2010.00115.x

16. Darukaradhya J, Phillips M, Kailasapathy K. Selective enumeration of Lactobacillus acidophilus, Bifidobacterium spp., starter lactic acid bacteria and non-starter lactic acid bacteria from Cheddar cheese. International Dairy Journal. 2006;16(5):439445. doi: 10.1016/j.idairyj.2005.06.009

17. EL-Sayed H, Salama HH, EL-Sayed SM. Production of synbiotic ice cream. International Journal of ChemTech Research. 2014;7:138-147.

18. Favaro-Trindade CS, Bernardi S, Bodini RB, Carvalho Balieiro JCDeC, De Almeida E. Sensory acceptability and stability of probiotic microorganisms and vitamin C in fermented acerola (Malpighia emarginata DC.) ice cream. Journal of Food Science. 2006;71(6):S492-S495. 10.1111/j.1750-3841.2006.00100.x

19. Godward G, Sultana K, Kailasapathy K, Peiris P, Arumugaswamy R, Reynolds N. The importance of strain selection on the viability and survival of probiotic bacteria in dairy foods. Milchwissenschaft. 2000;55(8):441-445.

20. Gomes AMP, Malcata FX. Bifidobacterium spp. and Lactobacillus acidophilus: biological, biochemical, technological and therapeutical properties relevant for use as probiotics. Trends in Food Science \& Technology. 1999;10(4-5):139-157. doi: 10.1016/ S0924-2244(99)00033-3

21. Guler-Akin MB, Goncu B, Akin MS. Some properties of probiotic yoghurt ice cream supplemented with carob extract and whey powder. Advances in Microbiology. 2016;6(14):1010. doi: 10.4236/aim.2016.614095

22. Hill C, Guarner F, Reid G, et al. The International Scientific Association for Probiotics and Prebiotics consensus statement on the scope and appropriate use of the term probiotic. Nat Rev Gastroenterol Hepatol. 2014;11:506-514. doi: 10.1038/nrgastro.2014.66

23. Homayouni A, Ehsani MR, Azizidagger A, Razavi SH, Yarmand MS. Spectrophotometricaly evaluation of probiotic growth in liquid media. Asian Journal of Chemistry. 2008;20(3):2414-2420.

24. Homayouni A, Ehsani MR, Mousavi SM, Valizadeh M, Djome ZE. Improving the quality of low-fat ice cream by hydrolyzing of casein micelles with chymosin (I)Instrumental evaluation. Iranian Journal of Agricultural Sciences. 2005;36(3):765-773.

25. Kalicka D, Znamirowska A, Pawlos M, Buniowska M, Szajnar K. Physical and sensory characteristics and probiotic survival in ice cream sweetened with various polyols. International Journal of Dairy Technology. 2019;72(3):456-465. doi: 10.1111/1471-0307.12605

26. Kurmann JA, Rasic JL. The Health Potential of Products Containing Bifidobacteria. Therapeutic Properties of Fermented Milks. Applied Food Sci. Elsevier, London. 1991:117-158

27. Mohammadi R, Mortazavian AM, Khosrokhavar $R$, da Cruz AG. Probiotic ice cream: viability of probiotic bacteria and sensory properties. Annals of Microbiology. 2011;61(3):411-424. doi: 10.1007/

\section{s13213-010-0188-z}

28. Mortazavian AM, Sohrabvandi S. Probiotics and food probiotic products; based on dairy probiotic products. Eta Publication, Tehran. 2006.

29. Oliveira MN, Remeuf F, Corrieu G. Effect of milk supplementation and culture composition on acidification, textural properties and microbiological stability of fermented milks containing probiotic bacteria. International Dairy Journal. 2001;11(1112):935-942. doi: 10.1016/S0958-6946(01)00142-X

30. Ozturk HI, Demirci T, Akin N. Production of functional probiotic ice creams with white and dark blue fruits of Myrtus communis: The comparison of the prebiotic potentials on Lactobacillus casei 431 and functional characteristics. LWT. 2018;90:339-345. doi: 10.1016/j. Iwt.2017.12.049

31. Pandiyan C. Preparation of functional ice cream using inulin, whey protein concentrate and lactobacillus acidophilus. Journal of Environment and Bio-sciences. 2014;28(2):159-162

32. Pandiyan C, Villi AR, Kumaresan G, Murugan B, Gopalakrishnamurthy TR. Development of synbiotic ice cream incorporating Lactobacillus acidophilus and Saccharomyces boulardii. International Food Research Journal. 2012a;19(3):1233-1239.

33. Pandiyan C, Villi AR, Kumaresan G, Murugan B, Rajarajan G. Effect of incorporation of inulin on the survivability of Lactobacillus acidophilus in synbiotic ice cream. International Food Research Journal. 2012b;19(4):1729-1732

34. Prashanth P, Singh JK, Maloo S, Bhaskar V. Enrichment of probiotic ice-cream with prebiotic green banana flour (Resistant starch). Int J Food Sci Nutr. 2018;3;6:190-193

35. Rastall RA. Functional oligosaccharides: application and manufacture. Annual Review of Food Science and Technology. 2010;1:305-339. doi: 10.1146/annurev. food.080708.100746

36. Rybka S, Kailasapathy K. The survival of culture bacteria in fresh and freeze-dried $A B$ yoghurts. Australian Journal of Dairy Technology. 1995;50(2):51-57.

37. Salem MM, Fathi FA, Awad RA. Production of probiotic ice cream. Polish Journal of Food and Nutrition Sciences. 2005;14(3):267-271.

38. Sangsila A, Faucet-Marquis V, Pfohl-Leszkowicz $A$, Itsaranuwat P. Detoxification of zearalenone by Lactobacillus pentosus strains. Food Control. 2016;62:187-192. doi: 10.1016/j.foodcont.2015.10.031

39. Sanz Y. Ecological and functional implications of the acid-adaptation ability of Bifidobacterium: a way of selecting improved probiotic strains. International Dairy Journal. 2007;17(11):1284-1289. doi: 10.1016/j. idairyj.2007.01.016

40. Saxelin M, Grenov B, Svensson U, Fonden R, Reniero R, Mattila-Sandholm T. The technology of probiotics. Trends in Food Science \& Technology. 1999;10(12):387-392. doi: 10.1016/S09242244(00)00027-3

41. Tamime AY, Saarela M, Sondergaard AK, Mistry VV, Shah NP. Production and maintenance of viability of probiotic microorganisms in dairy products. Probiotic Dairy Products. 2005;1:39-63. doi: 10.1002/9780470995785.ch3 
42. Thaochalee M, Amornsin A, Itsaranuwat P. Synbiotic ice cream containing germinated KDML105 rice flour and Lactobacillus acidophilus LA-5: physicochemical, probiotic viability and sensory evaluation. International Journal of Agricultural Technology. 2018;14(6):933948.

43. Tharmaraj N, Shah NP. Selective enumeration of Lactobacillus delbrueckii ssp. bulgaricus, Streptococcus thermophilus, Lactobacillus acidophilus, bifidobacteria, Lactobacillus casei, Lactobacillus rhamnosus, and propionibacteria. Journal of Dairy Science. 2003;86(7):2288-2296.

44. Turgut T, Cakmakci S. Investigation of the possible use of probiotics in ice cream manufacture. International Journal of Dairy Technology. 2009;62(3):444-451.

45. Vardar NB, Oksuz O. Artisan strawberry ice cream made with supplementation of Lactococci or Lactobacillus acidophilus. Italian Journal of Food Science. 2007;19(4):403-411.

46. Vijayageetha V, Begum SK, Reddy YK. Technology and quality attributes of probiotic ice cream. Tamilnadu Journal of Veterinary \& Animal Sciences. 2011;7(6):299302.
47. Vinderola CG, Prosello W, Ghiberto D, Reinheimer JA. Viability of probiotic (Bifidobacterium, Lactobacillus acidophilus and Lactobacillus casei) and nonprobiotic microflora in Argentinian Fresco cheese. Journal of Dairy Science. 2000;83(9):1905-1911. doi: 10.3168/ jds.S0022-0302(00)75065-X

48. Vinderola CG, Reinheimer JA. Enumeration of Lactobacillus casei in the presence of L. acidophilus, bifidobacteria and lactic starter bacteria in fermented dairy products. International Dairy Journal. 2000;10(4):271-275. doi: 10.1016/S09586946(00)00045-5

49. Vital ACP, Santos NW, Matumoto-Pintro PT, da Silva Scapim MR, Madrona GS. Ice cream supplemented with grape juice residue as a source of antioxidants. International Journal of Dairy Technology. 2018;71(1):183-189. doi: 10.1111/14710307.12412

50. Zhang S, Hu H, Wang L, Liu F, Pan S. Preparation and prebiotic potential of pectin oligosaccharides obtained from citrus peel pectin. Food chem. 2018;244:232-237. doi: 10.1016/j.foodchem.2017.10.071 